\title{
Baltimore City's landmark alcohol and tobacco billboard ban: an implementation case study
}

\author{
Peter L Meisel, Alicia Sparks, Raimee Eck, David Jernigan
}

\section{INTRODUCTION}

Alcohol is the leading cause of death and disability globally among males aged 15-24 in all regions except the Eastern Mediterranean and females aged 15-24 in the wealthy nations and the Americas; much of this burden is from injury. ${ }^{1}$ Excessive alcohol use is the leading drug problem among young people in the USA, ${ }^{2}$ and the leading causes of alcohol-related deaths among young people in the USA are injury: MVCs, homicide, suicide, poisoning (not alcohol), child maltreatment and drowning comprise 95\% of the approximately 4173 deaths caused by alcohol among persons under 21 annually. ${ }^{3}$ Exposure to alcohol advertising increases the likelihood that young people will hold positive beliefs about alcohol, intend to drink and consume alcohol. ${ }^{4-6}$ Longitudinal studies have consistently found that youth exposure to alcohol advertising in various settings_including broadcast, print, outdoor, point-of-purchase and at sporting events-correlates with earlier onset of drinking among non-drinkers and increased levels of drinking among youth already drinking. ${ }^{78}$ Adolescents who report exposure to and liking of ads in early adolescence (7th grade) are more likely later (10th grade) to report negative alcohol-related consequences, including getting into fights. ${ }^{9}$

Outdoor advertisements target pedestrian and motor vehicle traffic and appear in a wide array of formats and sizes. In the early 1990s, tobacco companies were the most prominent outdoor advertisers: in 1992 , the tobacco industry spent $\$ 123$ million on outdoor advertising and by 1996 six of the top ten outdoor advertisers were tobacco companies. ${ }^{10}$ Following the Master Settlement Agreement in 1998, outdoor advertising for tobacco fell precipitously, and expenditures on outdoor advertising for alcohol surpassed spending on tobacco ads. By 2002, the Anheuser-Busch Company was the largest

Johns Hopkins Bloomberg School of Public Health, Baltimore, Maryland, USA

Correspondence to David Jernigan, Department of Health, Behavior and Society, Johns Hopkins Bloomberg School of Public Health, $624 \mathrm{~N}$. Broadway, Room 292, Baltimore, MD 21205, USA; djernigan@ jhu.edu outdoor advertiser in the USA, spending just under $\$ 50$ million annually on outdoor advertisements. ${ }^{11}$

Saffer and Dave ${ }^{12}$ assessed the impact of alcohol advertising restrictions in 20 countries over 26 years and estimated that each incremental restriction reduced population-level alcohol consumption by $5-8 \%$. The same authors used advertising expenditure data to estimate that a $28 \%$ reduction in youth exposure to alcohol advertising, including outdoor advertising, would correlate with reductions of monthly adolescent binge drinking from $12 \%$ to between 11 and $8 \% .^{13}$ However, to the best of our knowledge, no studies have specifically examined the effects of bans on outdoor alcohol advertising on youth alcohol consumption.

Historically, states and the federal government have relied on alcohol industry self-regulation as the primary protection against youth exposure to alcohol advertising. ${ }^{14}$ However, industry failure to uphold its own standards of regulationparticularly in more vulnerable lowerincome, urban communities-resulted in grassroots activism and groundbreaking legislation to regulate alcohol advertising. ${ }^{15}$ Significant changes occurred in local regulation of outdoor advertising for alcohol throughout the country, but while the legal aspects underpinning this movement have been documented in peerreviewed literature, ${ }^{16}$ to our knowledge no one has documented the process that led to these changes or their implementation and enforcement. This paper seeks to fill that gap by reviewing the history of outdoor alcohol advertising regulation in Baltimore City, which passed the first municipal ordinance banning alcohol and tobacco advertising in the USA in 1994, from the ordinance's conception through legal hurdles and into implementation and enforcement, with a particular focus on the critical role that community organising and mobilisation played throughout the campaign.

To produce this case study, the authors reviewed newspaper coverage of the events in Baltimore, as well as relevant Baltimore City and Court documents, including written opinions of the
Baltimore City Circuit Court and United States Fourth Circuit Court of Appeals. The first author supplemented these with interviews of a range of key informants, including community activists, policymakers and city zoning officials; the first author also conducted an informal survey of Baltimore neighbourhoods to assess current implementation of the ordinance.

\section{EARLY EFFORTS TO RESTRICT} ALCOHOL AND TOBACCO BILLBOARDS

In the 1980s and early 1990s, numerous urban minority communities began documenting and publicising what they viewed as a growing problem: disproportionate targeting of their communities by alcohol and tobacco billboard advertising. ${ }^{15} \quad 17$ Prior to that time, few efforts had been made to restrict or regulate the amount and locations of billboard advertising for alcohol or tobacco products. In 1988, County Commissioner Alberta Tinsley-Williams of Wayne County, Michigan, recognised the disparity in advertising and led the first wellpublicised campaign against alcohol and tobacco billboard advertisements. ${ }^{18} \mathrm{Her}$ campaign inspired other cities and organisations to combat the presence of alcohol and tobacco billboards in low-income communities.

One of the first communities to build upon Tinsley-Williams' actions was Harlem, New York, where Reverend Calvin Butts led community activists and his Abyssinian Baptist Church congregation against alcohol and tobacco billboard advertising by whitewashing billboards they felt specifically targeted children or were too close to places of worship. ${ }^{16}$ Following the whitewashing of several billboards, the Metropolitan Outdoor Advertising Company negotiated a compromise with Rev. Butts, agreeing in March 1990 to remove alcohol and tobacco billboards within five blocks of all schools, churches and playgrounds. ${ }^{19}$ Yet without a legislative basis for ensuring the enforcement of Metropolitan's selfimposed limits, the compromise was rarely followed.

This story repeated itself in a number of cities and localities, including Chicago, Milwaukee and Santa Fe, where communities fought to hold billboard companies accountable when they failed to selfregulate and repeatedly found they lacked legal power for enforcement. ${ }^{16} 1920$ Kentucky and Texas were the first states to pass legislation regulating tobacco advertising at the state level, restricting the proximity of tobacco billboards to schools and churches in the early 1990s. ${ }^{16}$ In 


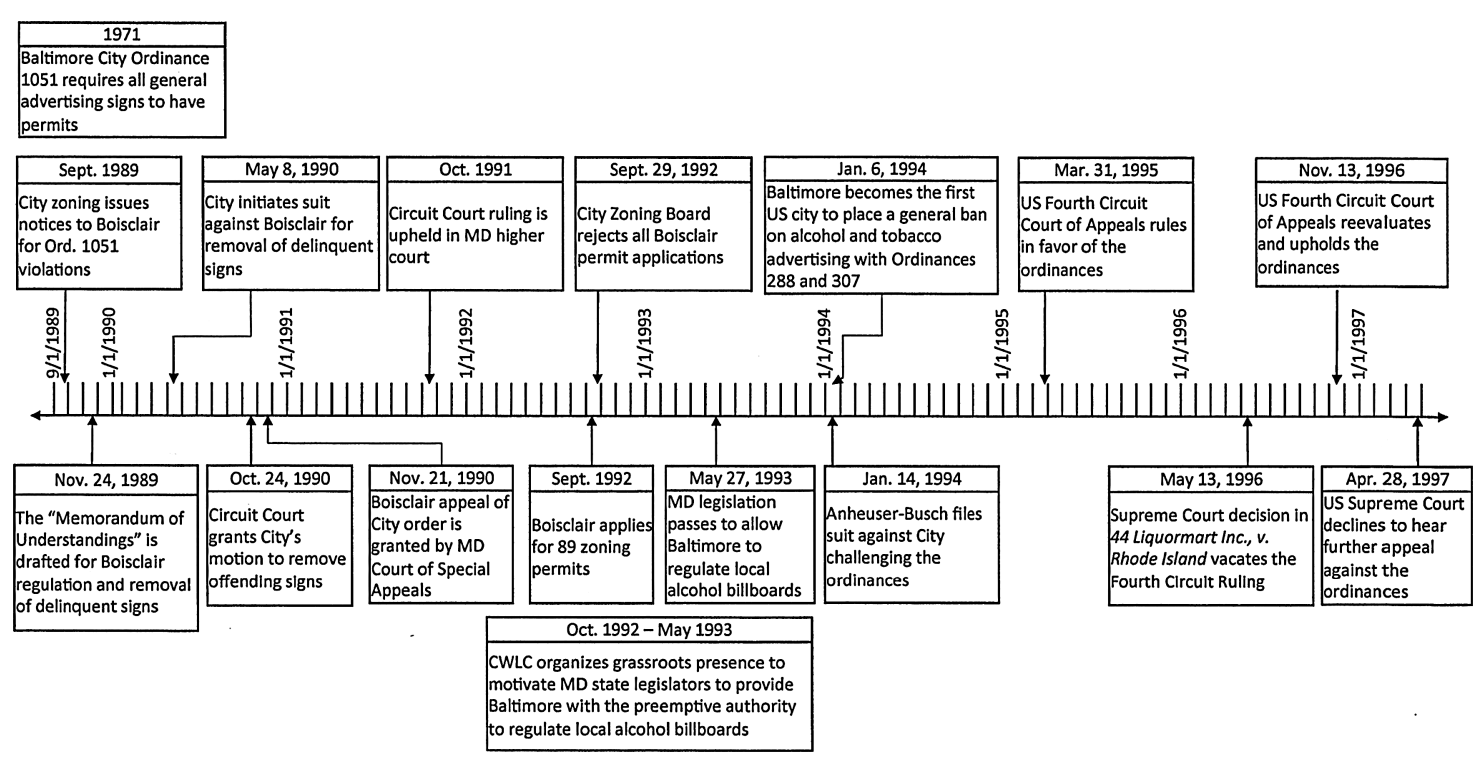

Figure 1 Timeline of events leading to enactment of Baltimore City's alcohol and tobacco billboard ban.

1994, Baltimore City became the first city to regulate alcohol and tobacco outdoor advertising within its borders through legislative action.

\section{BALTIMORE CITY STAGE ONE: REGULATING THROUGH EXISTING ZONING CODES}

In 1950, Baltimore City enacted its first billboard zoning law (Ordinance 1101). The city recodified the ordinance in 1971 to add business and industrial districts (Ordinance 1051-see figure 1 for a timeline of the Baltimore events). The ordinance required all general advertising signs to be approved with a permit from the zoning commission. It banned billboards in residential neighbourhoods and provided authority for the removal of nonconforming signs. ${ }^{21}$ However, these ordinances were rarely enforced. By 1990, Baltimore City had roughly 900 illegal (non-permitted) junior billboards (signs measuring roughly $6^{\prime}$ by $10^{\prime}$ attached most often to taverns, liquor stores and row houses) in residential neighbourhoods and 390 illegal junior billboards in business and industrial zones. ${ }^{22}$ Local activists argued that there were significant disparities in the placement of these signs in Baltimore City. Compared with the surrounding Baltimore County, the predominantly African-American Baltimore City had four times as many alcohol and tobacco billboards despite the fact that Baltimore City was more than 500 square miles smaller than the County and had nearly 80000 fewer residents. ${ }^{23}$ These findings were consistent with a 1985 Center for Science in the Public Interest study that had showed junior billboard advertising nationwide to be almost exclusively targeted at the African-American community-even in cities where African-American residents were a small percentage of the population. ${ }^{24}$

In the late 1980s, Baltimore community leaders and activists began to move against the advertising of products that were damaging neighbourhoods. ${ }^{25}$ The driving organisation for Baltimore's community action was the Citywide Liquor Coalition for Better Laws and Regulations (CWLC), made up of more than 100 African-American neighbourhood associations, churches and civic groups. The CWLC was organised and staffed by the Citizens Planning and Housing Association (CPHA), Baltimore's oldest and largest community activist organisation.

This display of broad-reaching community support for the removal of alcohol and tobacco billboards pressured Baltimore's elected officials to prioritise this issue. ${ }^{26}$ In September 1989, the Baltimore City Zoning Administration issued several notices to the Boisclair Advertising Company informing it that many of its signs were in violation of existing ordinances and demanding the removal of these billboards. ${ }^{21}$ Upon receiving the notices, Boisclair President James Eatrides initiated negotiations with Baltimore Mayor Kurt Schmoke, resulting in a Memorandum of Understanding signed on 24 November 1989 and calling for the immediate removal of alcohol and tobacco advertisements located within 'close proximity' to school and church buildings in the city, the gradual withdrawal of another roughly 400 Boisclair billboards from residential zoning districts, and a reduction in the percentage of outdoor advertisements dedicated to alcohol and tobacco products. ${ }^{21}$

\section{BALTIMORE CITY STAGE TWO: REGULATING THROUGH LITIGATION}

Although an agreement had been reached, removal of alcohol and tobacco advertisements in residential areas stalled. ${ }^{26}$ Dissatisfied with Boisclair's progress, community organisations lobbied the Baltimore Mayor to push for a more restrictive policy that would remove all alcohol and tobacco billboards throughout the city, rather than just focus on the areas near churches and schools. On 8 May 1990, Baltimore City initiated a lawsuit in Baltimore City Circuit Court in an effort to force the removal of alcohol and tobacco outdoor advertisements. ${ }^{27}$

On 24 October 1990, Circuit Judge Joseph H. H. Kaplan found that the city had legal grounds to enforce its zoning laws and that hundreds of Boisclair's billboards were therefore illegal and had to be removed. ${ }^{26}$ Boisclair elected to appeal Judge Kaplan's decision and won a stay on the City's order to remove all signs pending the outcome of that appeal. ${ }^{26}$ As a result of the stay, there was no reduction in the amount of alcohol and tobacco billboards on display throughout the city and in Baltimore's low-income residential neighbourhoods. ${ }^{28}$

On 30 October 1991, Maryland's higher court upheld the Circuit Court's decision that the billboards in violation of the original ordinances were illegal and had to be removed.

Although this affirmation of the Circuit Court's decision confirmed that the illegal alcohol and tobacco billboards had to be removed, it allowed alcohol and tobacco billboards not in violation of the city's 
zoning laws to remain. In September 1992, Baltimore's zoning board rejected each of the 84 junior billboard zoning permit applications submitted by Boisclair Advertising and Chesapeake Outdoor Enterprises. While the zoning board's actions were a victory for Baltimore's community activists and City Council, they were recognised by the advertising industry as a threat, prompting increased resistance against the city's legislative efforts. $^{27}$

\section{BALTIMORE CITY STAGE THREE: THE LOCAL BAN}

Faced with the billboard companies' ability to legally advertise alcohol and tobacco products by obtaining permits, community activists urged the Baltimore City Council and Mayor Schmoke to return to their earlier stance (prior to Judge Kaplan's decision) and ban such advertising altogether. While the activists received strong support from City Council members, the state of Maryland had pre-emptive power over Baltimore on alcohol issues. This meant that the state would first have to pass legislation allowing restriction and enforcement to be handled at the local level before Baltimore could enact its own regulations.

While CWLC had the support of Baltimore Mayor Schmoke as well as City Solicitor Neal Janey in its efforts to remove the state preemption, its greatest strength lay in the sweeping support for this initiative throughout Baltimore's neighbourhoods. ${ }^{25}$ Grandmothers associated with the coalition conducted a telephone campaign to raise awareness and encourage participation in the movement. At the same time, the CWLC initiated a lobbying effort in Annapolis to encourage billboard regulation legislation. Maryland Delegate Elijah Cummings championed the bill in the House and told members he felt as though all of the grandparents had come to Annapolis and were holding him accountable: "I've gotten more calls from everyday people in favor of this bill than any other issue. People are saying, "We want to save our children". 25

Despite heavy resistance from the billboard industry, the bill passed the Maryland House and Senate and Governor William Schaeffer signed it into law on 27 May 1993. The CWLC went back to the City Council, and on 6 January 1994, Baltimore became the first US city to place a general ban on alcohol and tobacco billboard advertising. Ordinance 288 addressed alcohol and Ordinance 307 addressed tobacco advertising in 'publically visible locations'. These ordinances regulated outdoor billboards, signage on the sides of buildings and freestanding signboards, but excepted industrial and business zones where children would not typically be found, including licensed premises, buses or cabs, stadiums and areas adjacent to interstate highways.

Political leaders in Baltimore on both sides of the issue recognised the importance of community action in procuring passage of the new legislation. "Credit for [the passing of the ordinances] is singularly due to the CPHA and the Liquor Coalition. Had it been up to the council, I think it would have been a dead issue", said City Council member Norman A. Handy Sr. ${ }^{23}$ Jim Eatrides, speaking for one of the billboard advertising companies, credited the City's legislative success to the community activists whom he referred to as 'zealots and a wellorganised minority'. ${ }^{23}$

\section{BALTIMORE CITY STAGE FOUR: LEGAL CHALLENGES}

Enforcement of the new ordinances was delayed again, however, by legal challenges claiming violations of the First and Fourteenth Amendment protections of free and commercial speech.

A challenge from Anheuser-Busch, the largest beer company in the USA, ultimately resulted in a judicial ruling (Anheuser-Busch, Inc., v. Schmoke, 101 F.3d 325 [4th Cir., 1996]) that Baltimore's ordinances were fair and reasonable regulations to defend the health and safety of the citizens of Baltimore. In his opinion, Justice Paul V. Neimeyer of the United States Fourth Circuit Court of Appeals acknowledged that outdoor billboards are unique in that they subject the public to involuntary and unavoidable forms of solicitation', and therefore upheld the city's right to regulate advertisements in large part because of the government's interest in promoting the health and safety of minors. The US Supreme Court, on 28 April 1997 (117 S. Ct. 1569), declined to hear an appeal, in essence upholding Justice Neimeyer's ruling.

\section{BALTIMORE CITY STAGE FIVE: IMPLEMENTATION}

Once the courts affirmed the legality of the ordinances, Baltimore could finally take action to enforce the billboard regulations using the threat of fines from the City Zoning Administration to ensure compliance. The Zoning Administration had a list of both permitted and non-permitted billboards, and their first action was to drive through the city and check each billboard for compliance. Any non-compliant billboards resulted in violation notices for the land and billboard owners. Violators were issued warnings, and a second notice would have received a $\$ 350$ criminal citation. ${ }^{27}$

By the conclusion of the Anheuser-Busch suit, nearly all of the non-compliant billboards in Baltimore belonged to Chesapeake Outdoor Enterprises and the Penn Advertising Company. Faced with the threat of significant fines, both companies complied. Within a few weeks of the court's decision, the owners had removed all non-compliant alcohol and tobacco billboards in the city without a single fine being issued. The number of alcohol and tobacco billboards in Baltimore City fell from more than 1300 to roughly 70 (those in locations exempted by the law). ${ }^{16}$

Baltimore's zoning administration still enforces the alcohol and tobacco billboard ordinances through threat of fines. However, it lacks the resources to conduct active monitoring of compliance of alcohol or tobacco billboards in violation of the codes, and so relies on complaints from citizens or community groups to trigger enforcement. $^{29}$ On receipt of such a complaint, the zoning administration will investigate the billboard, and if it finds a violation, issue a warning to the responsible party with an allotted time permitted for the removal of the offending billboard. If the responsible party is still non-compliant, a $\$ 500$ (an increase from the $\$ 350$ fine in 1996) criminal citation is issued, and each time the zoning representatives return to the site, the fine doubles. Based upon the zoning administrator's discretion regarding the severity of the violation, these fines can double every $24 \mathrm{~h}$ for major violations or at longer intervals for minor violations.

\section{BALTIMORE CITY STAGE SIX: ENFORCEMENT}

In the spring and early summer of 2007, alcohol advertisements began to appear on billboards owned by Clear Channel Outdoor, Inc., around Baltimore City, with eight alcohol advertising billboards appearing in the Remington and Hampden neighbourhoods alone. ${ }^{30}$ These billboards caught the attention of Doug Anderson and Joan Anderson Floyd, community activists from Remington who had worked with zoning administrators in the past on other issues. Mr. Armstrong drove around his neighbourhood and "recognized that [alcohol advertising billboards] were all over the place". ${ }^{31}$ To assess the scope of the problem, Mr. Anderson visited several other neighbourhoods in the city and found multiple alcohol advertising billboards there as well. 
Community activists reached out to the zoning administration about the infractions, it responded swiftly with warnings and threats of fines, and the alcohol billboards came down. Illustrating the critical role that the community activists played, City Councilwoman Mary Pat Clarke thanked them 'for bringing the matter to light'. ${ }^{32}$

Baltimore's current Zoning Administrator Geoffrey Veale told the first author of this paper that he credits the community surveillance system with doing a good job regulating illegal billboards. ${ }^{29}$ While violation notices have been issued, Mr. Veale noted that rarely have the $\$ 500$ criminal citations been issued and that threats of heavy fines have increased the strength of the city's regulatory system. An informal survey of Baltimore City conducted by the Center on Alcohol Marketing and Youth in 2012 found that all signage identified in the survey was placed in keeping with the legal exceptions listed in the City's ordinance.

\section{DISCUSSION}

Baltimore's general ban on outdoor advertising of alcohol and tobacco shows the important role that community engagement and organising can play in enacting and enforcing public health policy. First, community groups brought the issue of outdoor signage to the attention of local officials. A grassroots campaign carried the effort over its first major barrier, the state preemption of local action. The organising community groups had already done at the state level helped win speedy passage of a local ordinance once the state preemption was removed. However, legal challenges delayed enforcement of the ordinance for more than 3 years. In the short term, implementation of the ordinance was straightforward, and the presence of alcohol and tobacco billboards dropped precipitously in Baltimore City. However, the ordinance provided no resources for active monitoring or enforcement over time. Community activists' documentation of violations of the ordinance 10 years after its initial implementation led to straightforward and rapid enforcement of the ordinance.

Although limits on alcohol advertising on billboards were a significant step forward in reducing the daily exposure of youth to such advertising, most cities and states have done little to reduce other forms of outdoor signage, such as advertisements visible from the street in windows of retail establishments. ${ }^{33}$ As communities seek to reduce the exposure of youth and other vulnerable populations to alcohol advertising, the central role of community-based advocacy in the Baltimore experience has implications for efforts elsewhere to restrict alcohol advertising and confirms the experience of communities in the San Francisco Bay area in maintaining the ban on alcohol advertising on their public transit system. ${ }^{34}$ Members of local communities can educate policymakers and politicians to prioritise public health concerns associated with alcohol advertising and marketing disproportionately impacting young adults, racial and ethnic minorities, and impoverished populations. They can also play a key role in implementation and enforcement, through continued surveillance and involvement with the issue beyond initial implementation of new restrictions.

\section{CONCLUSION}

Public health is increasingly looking to regulation of the 'built environment' through mechanisms such as local zoning authority. ${ }^{35} 36$ Strategies to alter health risks in the built environment will benefit from the history of the Baltimore experience in showing the role that civic engagement and organising can play in all stages of the change process, from conception through to ongoing implementation and enforcement.

Acknowledgements We thank Doug Anderson and Joan Anderson Floyd for their continued efforts in Baltimore and the generous time they provided us to discuss their involvement in this issue. We also thank Mel Freeman, Executive Director of Baltimore's CPHA, for providing us with the context and history of his organisation's involvement in the billboard ban, and Baltimore City Housing Zoning Administrator Geoffrey Veale for discussing the city's enforcement process with us.

Contributors All authors made substantial

contributions to the conception and design of the study, assisted with critical revisions for important intellectual content, gave final approval of the version to be published and agree to be accountable for all aspects of the study. PLM took primary responsibility for the acquisition of data; all authors contributed to the analysis and interpretation of the data.

Funding Preparation of this paper was supported by Cooperative Agreement Number 5U58DP002027 from the Centers for Disease Control and Prevention. Its contents are solely the responsibility of the authors and do not necessarily represent the official views of the Centers for Disease Control and Prevention.

\section{Competing interests None.}

Provenance and peer review Not commissioned; externally peer reviewed.

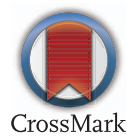

To cite Meisel PL, Sparks A, Eck R, et al. Inj Prev 2015;21:63-67.

Received 19 March 2014

Revised 10 June 2014

Accepted 1 July 2014

Published Online First 22 July 2014

Inj Prev 2015;21:63-67.

doi:10.1136/injuryprev-2014-041244

\section{REFERENCES}

1 Gore FM, Bloem PJ, Patton GC, et al. Global burden of disease in young people aged 10-24 years: a systematic analysis. Lancet 2011;377:2093-102.

2 Johnston LD, O'Malley PM, Bachman JG, et al. Monitoring the Future National Survey Results on Drug Use, Overview of Key Findings, 2012. Bethesda, MD: National Institute on Drug Abuse, 2012.

3 Centers for Disease Control and Prevention. Alcohol-Related Disease Impact Software. Secondary Alcohol-Related Disease Impact Software. 2013. http://apps.nccd.cdc.gov/DACH_ARDI/Default/Default. aspx

4 Collins RL, Ellickson PL, McCaffrey D, et al. Early adolescent exposure to alcohol advertising and its relationship to underage drinking. J Adolesc Health 2007;40:527-34.

5 Grube JW, Wallack L. Television beer advertising and drinking knowledge, beliefs, and intentions among adolescents. Am J Public Health 1994:84:254-59.

6 Martin SE, Snyder L, Hamilton M, et al. Alcohol advertising and youth. Alcohol Clin Exp Res 2002;26:900-06.

7 Anderson P, De Bruijn A, Angus K, et al. Impact of alcohol advertising and media exposure on adolescent alcohol use: a systematic review of longitudinal studies. Alcohol Alcohol 2009:44:229-43.

8 Smith LA, Foxcroft DR. The effect of alcohol advertising, marketing and portrayal on drinking behaviour in young people: systematic review of prospective cohort studies. BMC Public Health 2009:9:1-11.

9 Grenard JL, Dent CW, Stacy AW. Exposore to alcohol advertisements and teenage alcohol-related problems. Pediatrics 2013;131:e369-e79.

10 Hackbarth D, Schnopp-Wyatt D, Katz D, et al. Collaborative research and action to control the geographic placement of outdoor advertising of alcohol and tobacco products in Chicago. Public Health Rep 2001;116:558-67.

11 Communications C. 100 Leading National Advertisers. In: AdAge, ed. Special Report. New York, NY, 2003.

12 Saffer H, Dave D. Alcohol consumption and alcohol advertising bans. App/ Econ 2002;34:1325-34.

13 Saffer H, Dave D. Alcohol advertising and alcohol consumption by adolescents. Health Econ 2006;15:617-37.

14 Jernigan D, Ostroff J, Ross C. Alcohol advertising and youth: a measured approach. J Public Health Policy 2005;26:312-25.

15 Jernigan D, Wright PA. Making news, changing policy: case studies of media advocacy on alcohol and tobacco issues. Rockville, MD: University Research Corporation, Marin Institute, Center for Substance Abuse Prevention, 1994.

16 Garner DW. Banning tobacco billboards: the case for municipal action. JAMA 1996;275:1263-69.

17 Hackbarth D, Silvestri B, Cosper W. Tobacco and alcohol billboards in 50 Chicago neighborhoods: Market segmentatino to sell dangerous products to the poor. J Public Health Policy 1995;16:213-30.

18 Hundley T. Urban ads for tobacco, liquor come under fire. 1989. http://articles.chicagotribune.com/ 1989-02-12/business/8903040764_1_billboard-adsalberta-tinsley-williams-tobacco-and-alcohol

19 Valentine P. Billboard foes put up a fight; Baltimore activists say signs glamorize alcohol, tobacco. The Washington Post 1991.

20 Heise K. Henry Mcneil Brown, 61, Activist. Chicago Tribune 1996.

21 Harrell JJ. Chesapeake Outdoor Enterprises, INC v. City of Baltimore. In: Maryland CoSAo, ed. $89 \mathrm{Md}$ App 54. Maryland, 1991. 
22 Lolordo A. Judge orders firm to remove illegal city billboards. The Baltimore Sun 25 October 1990.

23 Stiehm J. Council to consider billboard proposals: recommendation seeks 12-month ban on new city signs. Baltimore Sun 1999.

24 Hacker GR, Collins R, Jacobson M. Marketing Booze to Blacks. In: Center for Science in the Public Interest, ed. Washington, D.C., 1985.

25 Themba MN. Making policy making change: how communities are taking law into their own hands. Oakland, CA: Chardon Press, 1999.

26 Evans M. Billboards can stay up, court rules Baltimore loses, pending an appeal. Baltimore Sun 1990.
27 Siegel E. 'Last Round' in billboard battle hearings for 89 permits are under way in city. Baltimore Sun 1992.

28 Thompson G. Community vows to tear down billboards. Baltimore Sun 1 May 1991.

29 Meisel P. Interview. In: Veale G, ed. Baltimore, 2012

30 Ericson E. Billboard busted; Clear Channel removes illegal billboards advertising liquor products. Baltimore City Paper 25 July 2007.

31 Meisel P. Interview with Doug Armstrong. Baltimore, MD, 2012.

32 Vozzella L. Take one drink each time a lawyer switches sides. The Baltimore Sun 25 July 2007.

33 Center on Alcohol Marketing and Youth. State laws to reduce the impact of alcohol marketing on youth: current status and model policies. Baltimore, MD: Johns Hopkins Bloomberg School of Public Health, 2012: $1-15$.

34 Simon M. Reducing youth exposure to alcohol ads: targeting public transit. J Urban Health 2008;85:506-16.

35 Ashe $\mathrm{M}$, Jernigan $\mathrm{D}$, Kline $\mathrm{R}$, et al. Land use planning and the control of alcohol, tobacco, firearms, and fast food restaurants. Am J Public Health 2003:93:1404-08.

36 Jackson RJ, Dannenberg AL, Frumkin H. Health and the built environment: 10 years after. Am J Public Health 2013:103:1542-44. 